\title{
Degradation of Insulin-Like Growth Factor-I Receptor Occurs Via Ubiquitin-Proteasome Pathway in Human Lung Cancer Cells
}

\author{
STEPHANA CARELLI, ${ }^{1,3}$ ANNA MARIA DI GIULIO, ${ }^{1}$ SIMONA PARATORE, \\ SILVANO BOSARI, ${ }^{2}$ AND ALFREDO GORIO ${ }^{1,3 *}$ \\ ${ }^{1}$ Laboratory of Pharmacology, Department of Medicine, Surgery, and \\ Dentistry, University of Milan, Milan, Italy \\ ${ }^{2}$ Pathology Unit, Department of Medicine, Surgery, and Dentistry, \\ University of Milan, Milan, Italy \\ ${ }^{3}$ Clinical Pharmacology, IRCCS Humanitas, Rozzano, Milan, Italy
}

\begin{abstract}
Insulin-like growth factor-I receptor (IGF-IR) is often overexpressed in malignant tumors, and is involved in the establishment and maintenance of malignant phenotypes. Tyrosine kinase receptor endocytosis is commonly triggered by ligand binding and occurs via clathrin-coated vescicles that transfer the receptor to the lysosome system for degradation. Our study aims at the evaluation of the mechanisms involved in IGF-IR downregulation in neoplastic (Npl) and non-neoplastic (non-Npl) cells. Exposure to insulin-like growth factor-I (IGF-I) of human lung adenocarcinoma cell lines (A549 and H1299) triggers IGF-IR ubiquitination and internalization processes that require energy and are preceded by the phosphorylation of receptor tyrosines. Differently from other plasma membrane substrates of the ubiquitin system, IGF-IR is degraded mostly by the proteasome in these tumor cell lines. The degradation is inhibited by lactacystin and unaffected by lysosomal inhibitors such as bafilomycin $\mathrm{A} 1$ and $\mathrm{NH}_{4} \mathrm{Cl}$. IGF-IR is processed in a similar manner also in fresh specimens of human lung tumors, while it requires active lysosomal functions in non-Npl human lung tissues. These results suggest that the degradation routes of ubiquitinated IGF-IR diverge in normal and Npl cells, and further support the involvement of IGF-IR signaling in cancer. Such a different route for IGF-IR processing might take place sometime during development, since both proteasome and lysosome pathways are active in fetal lung human fibroblasts, IMR90 cells.
\end{abstract}

J. Cell. Physiol. 208: 354-362, 2006. ㅇ 2006 Wiley-Liss, Inc.

Insulin-like growth factor-I (IGF-I) represents one of the major players in somatic cell growth during embryogenesis, neurogenesis, post-natal development, and metabolism in adult mammals (Jones and Clemmons, 1995; Werner, 1998; Carro et al., 2002). The pleiotropic cellular growth and the metabolic responses are regulated by its binding to the insulin-like growth factor type I receptor (IGF-IR) (Baserga, 1995; Stewart and Rotwein, 1996). This is often overexpressed in malignant tumors (Werner and Le Roith, 1997), and is likely involved in induction and maintenance of several human malignancies such as glio- and neuroblastomas, breast, lung, colon, and prostate carcinomas (Baserga et al., 1997; Werner and Le Roith, 1997; Ciechanover, 1998; Werner, 1998). IGF-IR is constituted by heterotetrameric $\alpha 2 \beta 2$ structure with two extracellular $\alpha$ subunits and two transmembrane $\beta$ sub-units containing tyrosine kinase domains (Ullrich et al., 1985; Di Guglielmo et al., 2003). IGF-IR activation results in the autophosphorylation of multiple tyrosine residues of the $\beta$ sub-units cytoplasmatic domain, which generates docking sites for src homology or phosphotyrosine binding domain-containing proteins, and leads to the phosphorylation/activation of several substrates, including insulin receptor substrate-1 (IRS-1) (Wang et al., 1993), and -2 (Sun et al., 1995), Shc proteins (Pronk et al., 1993), and Gab-1 (White and Kahn, 1994).

Most tyrosine kinase growth factor receptors are internalized after binding to their respective agonists (Robinson, 1994; Koenig and Edwardson, 1997) via clathrin-coated vescicles (Pearse and Robinson, 1990). Direct evidences and homologies with insulin receptor signaling pathway (Furlanetto, 1988; Carpentier, 1994) suggest that binding of IGF-I causes the shift of IGF-IR from the plasma membrane to early endosomes via clathrin-coated pits. Where, IGF-I/IGF-IR complex could be dissociated and inactivated by the acidic environment of late endosomes; ligands and receptors are sorted and directed to lysosome degradation or recycled to cell surface (Navab et al., 2001).

Several proteins, such as cell cycle regulators, tumor suppressors, oncoproteins, transcriptional activators, membrane and cytosolic endoplasmic reticulum-synthesized proteins, and cell surface receptors are processed and degraded via an ubiquitin-mediated pathway (Hicke, 1999; Ciechanover et al., 2000; Stang et al., 2000). Ubiquitin is conjugated to substrate proteins through the formation of an isopeptide bond between the $\varepsilon$ amino group of lysine residues in target proteins and its C-terminal glycin. The polyubiquitin chain is formed by successive addition of other ubiquitin moieties to the previously conjugated one; this chain constitutes a signal for recognition and destruction by the proteasome

Contract grant sponsor: MIUR; Contract grant number: RBAUOIL79J.

*Correspondence to: Alfredo Gorio, Department of Medicine, Surgery, and Dentistry, School of Medicine, University of Milan, Polo San Paolo, via A. Di Rudinì 8, 20142 Milan, Italy.

E-mail: alfredo.gorio@unimi.it

Received 14 February 2006; Accepted 17 March 2006

DOI: $10.1002 /$ jcp.20670 
(Ciechanover, 1998). A clear example is presented by the Saccaromyces cerevisiae, where pherormone binding determines phosphorylation and ubiquitination of Ste2p and Ste $3 p$ cytoplasmic tails; both modifications are required for rapid receptor internalization (Reneke et al., 1988; Hicke and Riezman, 1996; Roth and Davies, 1996). This ubiquitin-dependent processing has also been described in mammalian cells, and is characteristic for several proteins such as epidermal growth factor (EGF) and growth hormone (GH) receptors, and other plasma membrane proteins, that is, epithelial $\mathrm{Na}^{+}$ channel (Staub et al., 1997; Bonifacino and Weissman, 1998). Ubiquitination may represent a required structural modification for the initiation of receptor internalization (Strous et al., 1996). This process was recently shown for receptor tyrosine kinases (RTKs) in mammalian cells, where ligand-induced mono- and multiple-ubiquitinaton of RTKs determine their final fate, and initiates the receptor translocation from plasma membrane to lysosomes (Haglund et al., 2003).

In spite of IGF-IR crucial role in physiology and pathology, its degradation process is not yet known in great details. In this study, we monitored IGF-IR ligandinduced ubiquitination, and correlated such post-translational modification with its degradation. Here, we also report the differential fate of IGF-IR in neoplastic $(\mathrm{Npl})$ and non-neoplastic (non-Npl) human lung.

\section{MATERIALS AND METHODS Reagents}

Materials for sodium dodecyl sulphate-polyacrylamide gel electrophoresis (SDS-PAGE) were from Biorad (Hercules, $\mathrm{CA}$; lactacystin, antimycin A, bafilomycin A1, protein-A sepharose (PAS), protein-G sepharose (PGS) were from Sigma-Aldrich (St. Louis, MO); tissue culture sera and media were purchased from Euroclone (Figino, Milan, Italy); recombinant human IGF-I (rhuIGF-I) was kindly provided by Peprotech, Inc. (Rocky Hill, NJ) polyclonal antibodies against the $\beta$ chain of IGF-IR (C-20) and actin (C-11) were from SantaCruz Biotechnology (Santa Cruz, CA); polyclonal antibody against ubiquitin-conjugated proteins (UG9510) was from Biomol (Plymouth, PA); anti P-Tyr antibody (RC20H) was from BD Biosciences (San Jose, CA); polyclonal antibody against epidermal growth factor receptor (EGFR) (2232) was from Cell Signaling Technology (Beverly, MA). Reagents for enhanced chemiluminescence were from Amersham Biosciences (Uppsala, Sweden). All other reagents were of high analytical grade and were purchased from Sigma-Aldrich.

\section{Cells and cell cultures}

A549 (human epithelial-like lung adenocarcinoma) IMR90 (human normal lung of fetal origin) cell lines were obtained from the American Type Culture Collection (ATCC; Manassas, VA) and maintained in accordance with the manufacturer's instructions. H1299 (human lung carcinoma, non-small cell lung cancer (NSCLC) cell line was kindly provided by P.P. Di Fiore (Experimental Oncology, European Institute of Oncology, 20141 Milan; Department of Medicine, Surgery, and Dentistry, University of Milan, 20142 Milan) and maintained as indicated by ATCC's instructions. All cell lines were maintained at $37^{\circ} \mathrm{C}$ in a humidified atmosphere $\left(5 \% \mathrm{CO}_{2}\right.$ : 95\% air) and were routinely sub-cultivated by trypsinization to keep long-phase growth.

\section{Tissues and patients}

The study included $\mathrm{Npl}$ and non-Npl lung biopsies (paired samples from the same patient) from eight different patients affected by NSCLC, obtained from the Pathology Unit of the San Paolo Hospital, Milan. Informed consent was obtained from all of the patients. In all tumor specimens the amount of $\mathrm{Npl}$ cells was equal or exceeded $80 \%$ of the sample, confirmed by histological diagnosis.

\section{Ligand-induced IGF-IR degradation in cell lines}

Cell lines, physiologically expressing IGF-IR, were subconfluently grown and incubated for $16 \mathrm{~h}$ in serum-deprived culture medium. The experiment was performed in a complete culture medium at $1 \%$ fetal bovine serum (FBS). To inhibit protein synthesis the cells were subsequently incubated with cycloheximide (CHX, $10 \mu \mathrm{g} / \mathrm{ml})$ that was maintained during all of the assays. After 30 min, ligand IGF-IR internalization was induced incubating for different time periods with human recombinant IGF-I (rhuIGF-I) at the indicated concentrations. Proteasome and lysosome inhibitors (lactacystin, $10 \mu \mathrm{M}$; $\mathrm{NH}_{4} \mathrm{Cl}, 10 \mathrm{mM}$; bafilomycin A1 $1 \mu \mathrm{M}$; respectively) were added 5 min prior to IGF-I stimulation and were present throughout the experiment. Cell plates were harvested on ice, the medium was removed, and the cells were lysed on SDS containing buffer (2\% SDS, $0.1 \mathrm{M}$ NaAcetate, $0.5 \mathrm{mM}$ EDTA) and proteases inhibitors. Protein concentration was determined using the Lowry Ciocalteau's method with BSA as standard (Lowry et al., 1951). Equal amounts of solubilized protein $(50 \mu \mathrm{g})$ were dissolved in Laemmli sample buffer (Biorad), separated by SDS-PAGE in reducing conditions, and electroblotted onto nitrocellulose membranes. The blots were blocked in $5 \%$ nonfat milk, $0.05 \%$ Tween-20 in TBS $\mathrm{pH} 7.5$ and probed with specific antibodies.

\section{Ligand-induced IGF-IR degradation in lung biopsies}

Non-neoplastic and Npl lung biopsies obtained immediately after surgical resection were washed in PBS, cut in small bits, and incubated in medium supplemented with $1 \%$ heat-inactivated FBS, $1 \mathrm{mM}$ glutamine, $0.02 \mathrm{UI} / \mathrm{ml}$ penicillin, $0.02 \mathrm{UI} / \mathrm{ml}$ streptomycin. Ligand-induced IGF-IR degradation was performed in presence of rhuIGF-I $(50 \mathrm{ng} / \mathrm{ml})$ in the experimental conditions indicated before. The experiment was harvested by samples incubation on ice, medium removal, and washing with ice-cold PBS. Small bits were homogenized as indicated below. Equal amounts of protein extracts $(75 \mu \mathrm{g})$ were loaded on a gel, electroblotted, and IGF-IR $\beta$ chain expression was investigated by western blot as described.

\section{Non-Npl and Npl lung tissues' homogenization}

Biopsies were homogenized in isotonic condition $(25 \mathrm{mM}$ Tris-HCl pH 7.4, $250 \mathrm{mM}$ sucrose, $1 \%$ Triton X-100, 1\% NP-40, $5 \mathrm{mM}$ EDTA, 1mM EGTA, $1 \mathrm{mM}$ phenylmethylsulphonylfluoride, $1 \mathrm{mM}$ aprotinin, $1 \mathrm{mM}$ leupetin, $2 \mathrm{mM} \mathrm{Na}_{3} \mathrm{VO}_{4}, 2 \mathrm{mM} \mathrm{NaF}$ ) with ULTRA-TURRAX T25. Homogenates were centrifuged at $2,500 \mathrm{~g}$ for $20 \mathrm{~min}$ at $4 \mathrm{C}$, the supernatants were collected, and protein concentrations were determined with Lowry Ciocalteau's method with BSA as standard.

\section{IGF-I-stimulated protein tyrosine phosphorylation}

To determine IGF-IR $\beta$ chain tyrosine phosphorylation, subconfluently growing cells were incubated for $16 \mathrm{~h}$ in serumdepleted culture medium. IGF-I was added, or not, to the medium at the indicated concentration and maintained for different times. The medium was removed and the cells were washed twice with ice-cold washing buffer $(20 \mathrm{mM}$ Tris- $\mathrm{HCl} \mathrm{pH}$ 7.6, $137 \mathrm{mM} \mathrm{NaCl}, 1 \mathrm{mM} \mathrm{MgCl}, 1 \mathrm{mM} \mathrm{CaCl}_{2}, 0.1 \mathrm{mM} \mathrm{Na}_{3} \mathrm{VO}_{4}$ ) and lysed in RIPA buffer with $2 \mathrm{mM} \mathrm{Na}_{3} \mathrm{Vo}_{4}, 2 \mathrm{mM} \mathrm{NaF}$, and protease inhibitors. IGF-IR was immunoprecipitated and electroblotted on PVDF membrane as described above. The phosphorylated IGF-IR was detected by an anti-phosphotyrosine antibody.

\section{Immunoprecipitation and detection of ubiquitination conjugates}

Insulin-like growth factor-I receptor was immunopurified from human lung biopsies (non-Npl and $\mathrm{Npl}$ ) and from cell protein extracts under special condition to prevent deubiquitination and dephosphorylation (Govers et al., 1997). Protein extracts $(500 \mu \mathrm{g})$ were diluted in immunoprecipitation buffer (50 mM Tris-HCl pH 7.5, $150 \mathrm{mM} \mathrm{NaCl}, 1 \%$ Triton X100, $2 \mathrm{mM}$ EGTA, $2 \mathrm{mM}$ EDTA, $1 \%$ deoxycholic acid, $50 \mathrm{mM}$ $\mathrm{NaF}, 1 \mathrm{mM} \mathrm{Na} \mathrm{VO}_{4}, 10 \mu \mathrm{g} / \mathrm{ml}$ aprotinine, $10 \mu \mathrm{g} / \mathrm{ml}$ leupeptine, $5 \mathrm{mM}$ phenylmethylsulphonylfluoride), IGF-IR were immunoprecipitated using a polyclonal antibody against its $\beta$ chain at 
$4{ }^{\circ} \mathrm{C}$ overnight. Immunocomplexes were purified by adding PGS for $3 \mathrm{~h}$ at $4^{\circ} \mathrm{C}$ and recovered by centrifugation at $8,000 \mathrm{~g}$. Immunocomplexes-PGS were washed twice with high salt buffer $(50 \mathrm{mM}$ Tris-HCl pH 7.5, $500 \mathrm{mM} \mathrm{NaCl}, 0.1 \%$ Triton X$100,0.05 \%$ deoxycholic acid) and once with low salt buffer (10 mM Tris-HCl pH 7.5, 0.1\% Triton X-100, $0.05 \%$ deoxycholic acid). After elution in reduced Laemmli buffer at $95^{\circ} \mathrm{C}$ for $5 \mathrm{~min}$, samples were resolved on SDS-PAGE in reducing condition and transferred to nitrocellulose membranes. Blots were probed with rabbit polyclonal anti-ubiquitinated proteins, followed by horseradish peroxidase-conjugated goat antirabbit antibody (Chemicon, Temecula, CA). ECL ${ }^{\mathrm{TM}}$ detection system was used to visualize proteins.

\section{Quantitative evaluation of autoradiograms and statistical analyses}

The autoradiograms were analyzed using the NIH IMAGE 1.61 /fat program written by Wayne Rasband and a Macintosh computer. Results were statistically evaluated by Fisher's exact test, $P$-values $<0.05$ were considered statistically significant. All analyses were performed with GraphPad Prism 4.0 software.

\section{RESULTS \\ IGF-I receptor $\beta$ chain is a short-lived protein and its degradation in lung adenocarcinoma cells requires energy}

The stability of IGF-IR and the ATP requirement for its degradation were evaluated in A549 cells. The exposure to $50 \mathrm{ng} / \mathrm{ml}$ rhuIGF-I in presence of CHX
(10 $\mu \mathrm{g} / \mathrm{ml}$ ), a protein synthesis blocker, triggered the degradation of IGF-I receptor $\beta$ chain that within 120 and 240 min was reduced by $40 \%$ and $75 \%$, respectively (Fig. 1A lanes 1-3). On the other hand, the degradation of IGF-IR $\beta$ was impaired and the receptor expression remained unchanged (Fig. 1A lanes 4-6) when ATP was depleted by adding antimycin A to the culture medium (as described by Ciechanover et al., 2000). These data show that proteolytic processing of IGF-IR $\beta$ chain requires the IGF-I-mediated activation of the receptor and the presence of ATP. The addition of CHX alone (in absence of IGF-I) does not cause noticeable changes in IGF-IR $\beta$ chain expression.

\section{Time course of IGF-IR tyrosine phosphorylation correlates with its ubiquitination}

The time course of IGF-I-induced $\beta$ chain tyrosine phosphorylation and ubiquitination was determined by incubating A549 cells at $37^{\circ} \mathrm{C}$ with rhuIGF-I (50 ng/ml) for different times. Cell lysates were prepared, and cell extracts subjected to immunoprecipitation with antiIGF-IR $\beta$ chain antibody. To evaluate IGF-I receptor phosphorylation, the precipitates were then resolved by SDS-PAGE and immunoblotted with phosphotyrosine antibodies. As shown in Figure 1B, the phosphorylation of IGF-I receptor was rather quick and detectable within $2 \mathrm{~min}$, the maximum extent was achieved in $5 \mathrm{~min}$. The data quantification is shown in lower part of Figure 1B.
A

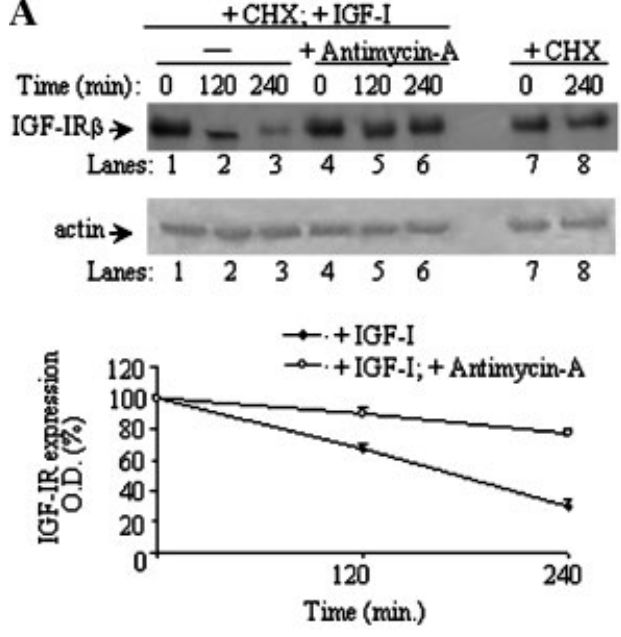

C

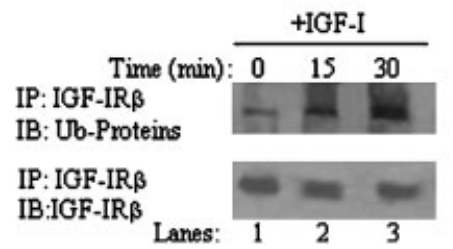

Fig. 1. IGF-IR $\beta$ chain degradation is ATP-dependent and its phosphorylation and ubiquitination are induced by IGF-I. A: In A549 cells degradation of IGF-IR $\beta$ chain was monitored as described in "Materials and Methods." The experiment was carried out adding rhuIGF-I (50 ng/ml) in absence (lanes 1-3) or presence (lanes 4-6) of antimycin A $(50 \mu \mathrm{M})$. Protein synthesis was blocked by adding CHX. After cell lysis, proteins were separated by SDS-PAGE and IGF-IR $\beta$ chain and $\beta$-actin, used as internal control of gel loading, were visualized as described in "Materials and Methods." IGF-I addition causes a drastic decrease of IGF-IR $\beta$ chain (lanes 1-3) that is prevented by antimycin A mediated ATP depletion (lanes 4-6), no IGF-IR decrease was observed when IGF-I was omitted (lanes 7-8). Band intensities were quantified and plotted as a relative percentage
B
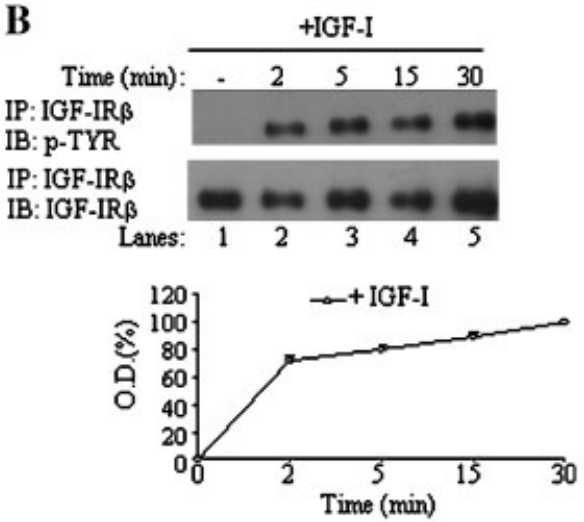

of the signal at time 0 . B: Phosphorylation of IGF-IR $\beta$ chain was studied incubating A549 cells with rhuIGF-I as described. Following IGF-IR $\beta$ chain immunoprecipitation, samples were analyzed on SDS-PAGE and electro-transferred to PVDF. IGF-IR $\beta$ chain phosphorylation was detected by an anti-phosphotyrosine antibody (lanes $1-5$, upper part). Band intensities were quantified, and plotted as a relative percentage of the signal at $30 \mathrm{~min}$. C: IGF-IR $\beta$ chain ubiquitination was determined with a polyclonal antibody as described in "Materials and Methods" (lanes 1-3, Ub-proteins in the upper part). All the experiments were repeated three times with similar results, and data are expressed as the mean of three independent experiments $\pm \mathrm{SD}$. 
Recently ubiquitination was proposed as a regulatory process for RTK endocytic transport from plasma membrane to lysosomes (Hicke, 1999; Haglund et al., 2003). In Figure 1C it is shown that the extent of IGF-IR $\beta$ chain ubiquitination increased during the exposure to its specific ligand.

A functional proteasome system is required for IGF-IR $\beta$ chain degradation in lung tumor cell lines

It is known that polyubiquitin tagging is suggestive of degradation via proteasome (Ciechanover, 1998), and we have just shown that IGF-IR $\beta$ chain is ubiquitinated and degraded by means of an ATP-dependent manner (Fig. 1). Lactacystin, an inhibitor of chymotrypsin- and

A

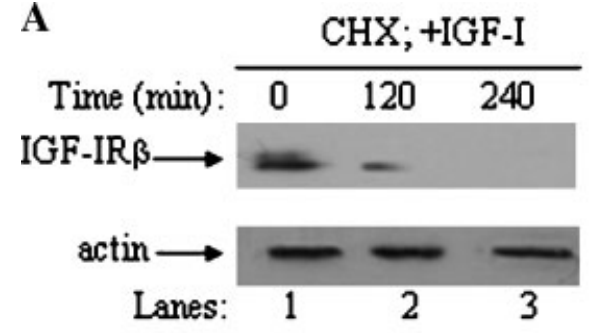

C

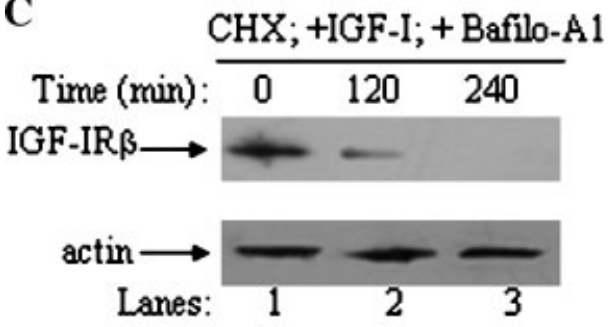

trypsin-like proteasomal proteases, and two lysosomal proteases inhibitors, $\mathrm{NH}_{4} \mathrm{Cl}$ and bafilomycin $\mathrm{A} 1$, were used for testing IGF-IR proteasomal degradation.

Lung tumor cells were sub-confluently grown, then incubated for $16 \mathrm{~h}$ in serum-deprived culture medium. The experiment was performed in a complete culture medium with $1 \%$ FCS, and CHX was added and maintained throughout the assay for inhibiting protein synthesis. Exposure of A549 cells to rhuIGF-I caused a marked reduction of IGF-IR $\beta$ chain that was already evident at $120 \mathrm{~min}$ (Fig. 2A,E). This ligand-induced degradation was prevented by the addition to the test medium of the proteasome inhibitor lactacystin (Fig. 2B,E). The amount of IGF-IR actually increased
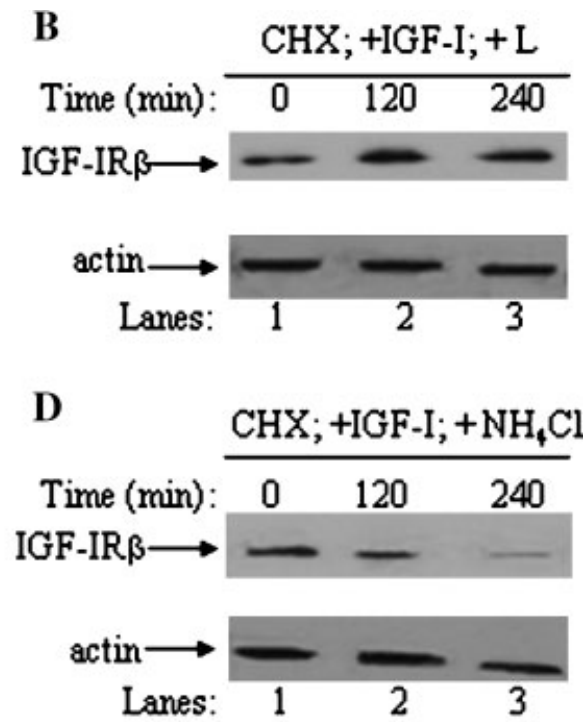

$\mathbf{E}$

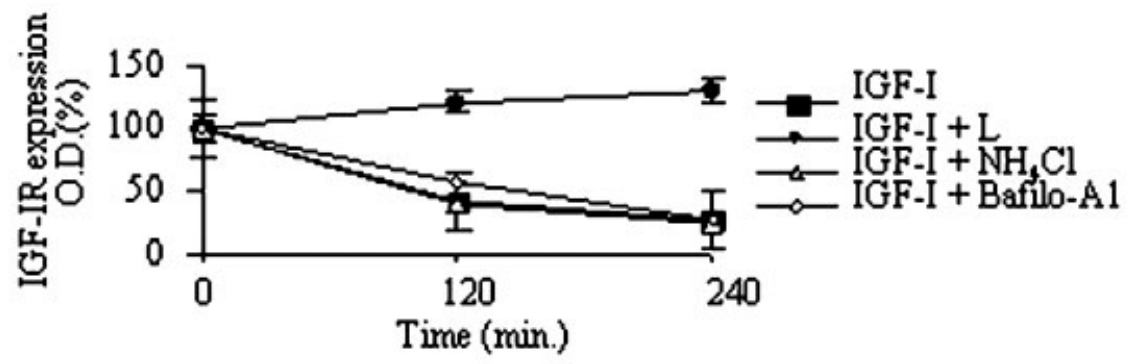

$\mathbf{F}$

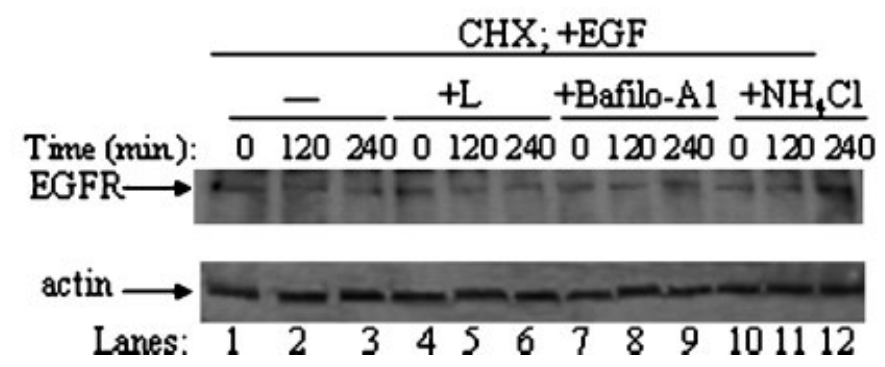

Fig. 2. IGF-IR $\beta$ chain degradation in A549. A-E: After starvation, A549 cells were incubated in medium supplemented with $1 \%$ serum, and pre-treated for $30 \mathrm{~min}$ with $\mathrm{CHX}(10 \mu \mathrm{g} / \mathrm{ml})$, which was maintained during the entire assay. rhuIGF-I $(50 \mathrm{ng} / \mathrm{ml})$ was added and maintained for the indicated time. Cells were lysed, protein separated by one-dimensional SDS-PAGE and IGF-IR $\beta$ chain was visualized by immunoblot as described before. A: The experiment was carried out in the absence of any protein degradation inhibitor, or (B) in presence of lactacystin $(\mathrm{L}, 10 \mu \mathrm{M})$, the levels of IGF-IR decreased in (A) and increased in (B). When the lysosome inhibitors,

(C) bafilomycin A1 (Bafilo-A1, $1 \mu \mathrm{M})$, and (D) $\mathrm{NH}_{4} \mathrm{Cl}(10 \mathrm{mM})$, were added IGF-IR levels decreased greatly within 120 min. E: Band intensities were quantified, normalized to $\beta$-actin levels, and plotted as a relative percentage of the signal at time 0 . F: Like in the case of IGF-IR, after cell starvation, EGFR degradation assays were performed by adding EGF $(20 \mathrm{ng} / \mathrm{ml})$ to the medium supplemented with $1 \%$ serum in presence or in absence of lysosome or proteasome inhibitors. Data are expressed as the mean of three independent experiments $\pm \mathrm{SD}$. 
at $240 \mathrm{~min}$, likely due to a progressive reduction of the inhibitory action by CHX on protein synthesis. In contrast, the blockade of lysosomal proteases with bafilomycin $\mathrm{A} 1$ (Fig. 2C,E) or $\mathrm{NH}_{4} \mathrm{Cl}$ (Fig. 2D,E) did not affect the degradation process. The functional activity of lysosomal system in lung tumoral cells was monitored by evaluating ligand-mediated degradation of EGFR in A549 cells in presence or absence of lysosome and proteasome inhibitors. The degradation process of EGFR is impaired by the blockade of the lysosomal system with $\mathrm{NH}_{4} \mathrm{Cl}$, while lactacystin does not influence the process (Fig. 2F). Thus the lysosomal system is present and active in lung cancer cells.

Ligand-induced ubiquitination and degradation of IGF-IR $\beta$ chain was also investigated in H1299 cells, another type of lung tumor cell line. The ubiquitination of IGF-IR $\beta$ chain was increased by 30 -min exposure to rhuIGF-I (Fig. 3A). While IGF-IR $\beta$ chain levels decreased to $40 \%$ of control values in $240 \mathrm{~min}$ (Fig. 3B,F), the co-incubation with lactacystin impaired this process and prevented IGF-IR degradation (Fig. 3C). This correlates with the increased ubiquitination of IGF-IR

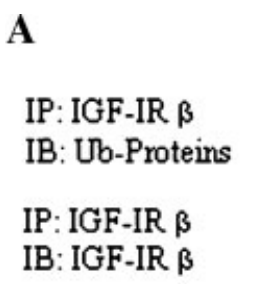

Lanes:
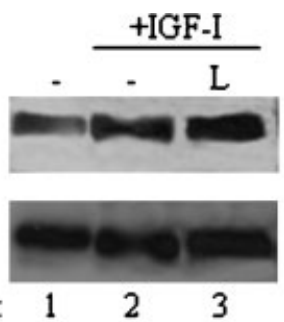

B

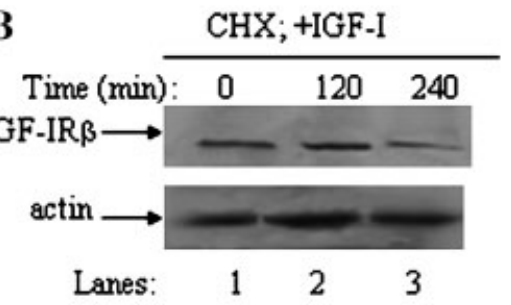

C

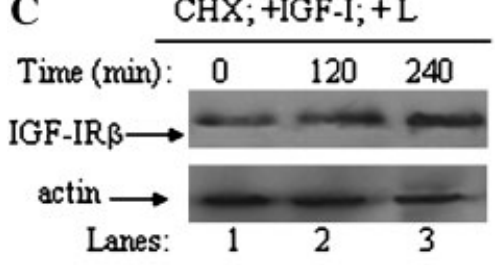

$\beta$ chain (Fig. 3A lane 3). Conversely, lysosome inhibitors did not influence the degradation process (Fig. 3D,E). The quantifications are shown in Figure 3 part F. All these data suggest that IGF-IR $\beta$ chain is degraded mostly by proteasome pathway in lung tumor cell lines.

\section{IGF-IR $\beta$ chain ligand-induced ubiquitination and degradation in lung tumor specimens}

Experimental and clinical studies have shown that IGF-IR is overexpressed in different carcinomas such as prostate, tyroid, colon, lung (Belfiore et al., 1999; Xie et al., 1999; Samani et al., 2004), and in synovial sarcoma (All-Ericsson et al., 2002). We evaluated the expression of IGF-IR $\beta$ chain in homogenates derived from non- $\mathrm{Npl}$ and $\mathrm{Npl}$ lung tissues of eight different patients. IGF-IR $\beta$ chain was expressed at higher levels in specimens of NSCLC compared to non-tumoral portion. The IGF-IR expression from samples of three patients is shown in Figure 4A, while the quantification of its expression for the eight patients, assessed by densitometric scanning of the band on autoradiographs, is shown graphically in Figure 4B. The IGF-IR from
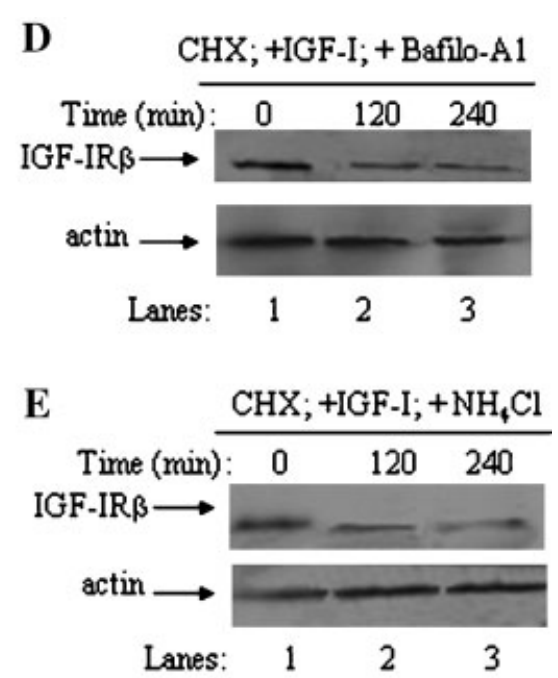

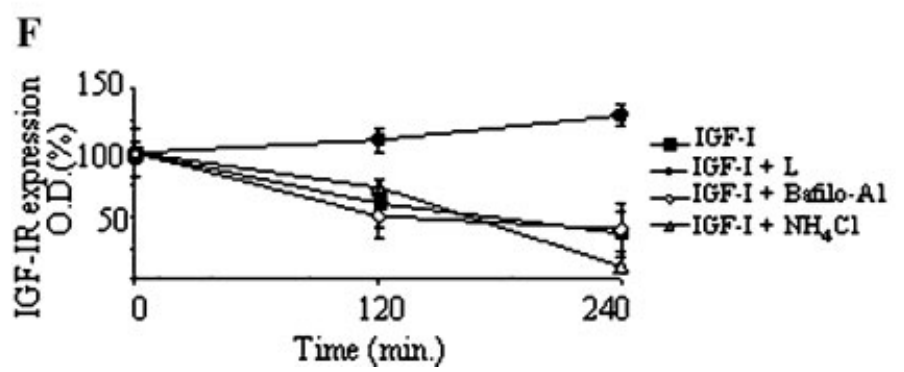

Fig. 3. IGF-IR $\beta$ chain ubiquitination and degradation in H1299. A: Ubiquitination of IGF-IR $\beta$ chain was investigated as described in "Materials and Methods" and with the same procedures described in the legend of Figure 3. IGF-I exposure enhances IGF-IR $\beta$ chain ubiquitination (A) and degradation (B-F). The co-administration of the proteasome inhibitor lactacystin $(\mathrm{L}, 10 \mu \mathrm{M})$ prevents such a loss

(C), while the presence of lysosome inhibitors (D) bafilomycin A (Bafilo-A1, $1 \mu \mathrm{M})$ and (E) $\mathrm{NH}_{4} \mathrm{Cl}(10 \mathrm{mM})$, do not modify IGF-I promoted receptor degradation. F: Quantitative data were plotted as described before. Data are expressed as the mean of three independent experiments \pm SD. 
homogenates of lung human $\mathrm{Npl}$ and non-Npl tissues was immunoprecipitated as described above for the cell lines. Precipitates were analyzed on SDS-PAGE and immunoblotted with a polyclonal antibody against ubiquitin-conjugated proteins. IGF-IR $\beta$ chain and its ubiquitination were more abundant in Npl compared to non-Npl fresh lung tissue samples (Fig. 4C). Couples of small bits from Npl and non-Npl lung biopsies of the same patient were incubated with rhuIGF-I $(50 \mathrm{ng} / \mathrm{ml})$ as it was done previously for the cell lines. IGF-IR $\beta$ chain phosphorylation increased significantly within 30 min in both Npl and non-Npl samples (Fig. 4D). IGFIR $\beta$ chain ubiquitination occurs also in tissue specimens and its extent increased within $15 \mathrm{~min}$ and remained as such at later check in non-Npl tissue specimens (Fig. 4E). Similar results were observed with Npl specimens (data not shown).
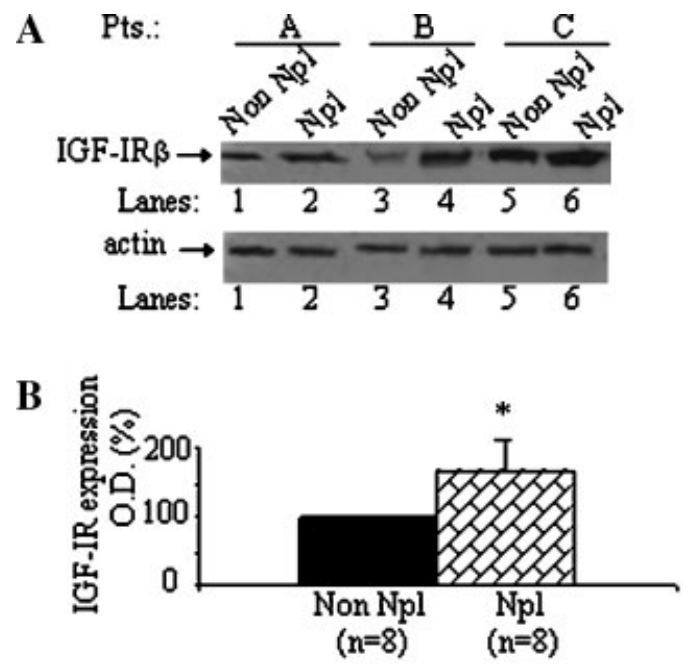

C

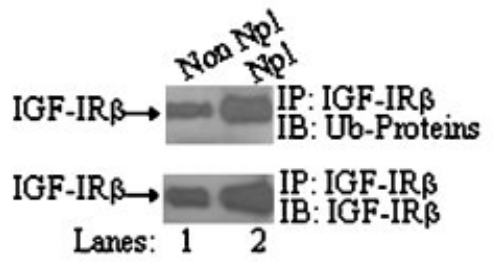

D

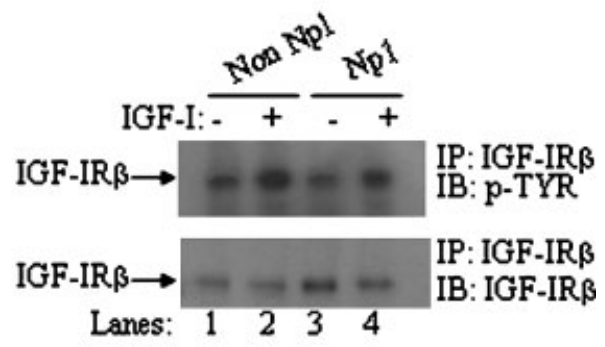

$\mathbf{E}$

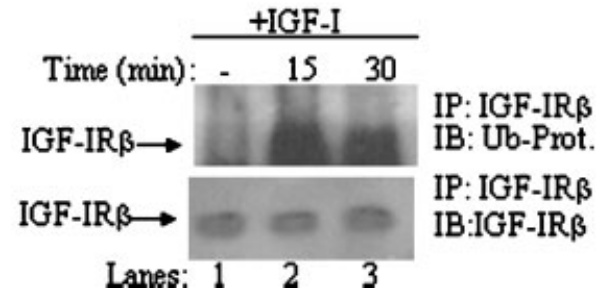

The ligand-induced IGF-IR $\beta$ chain degradation in fresh $\mathrm{Npl}$ and non-Npl lung tissue specimens from the same patient are shown in Figure 5. To inhibit protein neo-synthesis, small bits of tissue were pre-incubated for 30 min with CHX, which, thereafter, was maintained for the entire assay. In Npl lung specimens the addition of rhuIGF-I $(50 \mathrm{ng} / \mathrm{ml})$ for $240 \mathrm{~min}$ caused a $40 \%$ reduction of IGF-IR $\beta$ chain (Fig. 5A lanes 1 and 2). That was unaffected by the presence of $\mathrm{NH}_{4} \mathrm{Cl}$ in the incubation media (Fig. 5A lanes 5 and 6), and totally inhibited by lactacystin (Fig. 5A lanes 3 and 4). These data strongly support the conclusions derived from the experiments above with lung Npl A549 and H1299 cell lines. In non-Npl lung specimens the results were reversed. In 240 min of IGF-I exposure there was a $50 \%$ receptor loss, which was prevented by $\mathrm{NH}_{4} \mathrm{Cl}$, and unaffected by lactacystin (Fig. 5B).

IGF-IR $\beta$ chain degradation occurs via lysosome and proteasome systems in IMR90 cell line

IMR90 cells are normal lung fibroblast of fetal origin and represent a further control of our study on the IGFIR $\beta$ chain degradation in normal and $\mathrm{Npl}$ lung tissues. Thirty minutes exposure to IGF-I promotes receptor ubiquitination that is further increased by the coincubation with proteasome inhibitor lactacystin (Fig. 6A). Moreover, the same results were obtained by the co-incubation with the lysosome inhibitor $\mathrm{NH}_{4} \mathrm{Cl}$ (data not shown). IGF-IR $\beta$ chain degradation was promoted by co-incubation with IGF-I $(150 \mathrm{ng} / \mathrm{ml})$ and CHX $(10 \mu \mathrm{g} / \mathrm{ml})$, there was a loss of $120 \mathrm{~min}$ (Fig. 6B lanes 1-3). The further addition of either lactacystin or $\mathrm{NH}_{4} \mathrm{Cl}$ prevented such a drop (Fig. 6B lanes 4-9). Quantitative data are shown in part C of the same figure. The same results were obtained when IMR90 cells were incubated with bafilomycin A1 as lysosome inhibitor (data not shown).

\section{DISCUSSION}

This study shows that $\beta$ chain of IGF-IR is a substrate of the ubiquitin-proteasome system in human lung cancer cells. The blockade of one pathway at a time with lactacystin, an inhibitory agent specific for proteasome, or $\mathrm{NH}_{4} \mathrm{Cl}$ and bafilomycin A1, for lysosomes proteases, indicates that IGF-IR $\beta$ chain is degraded via the proteasome pathway in lung cancer cells grown in vitro

Fig. 4. IGF-IR $\beta$ chain expression, phosphorylation, and ubiquitination in non-Npl and NSCLC specimens. A, B: Protein extracts of paired non-Npl and Npl lung tissue specimens from eight patients affected of NSCLC (Materials and Methods) were immunoblotted with polyclonal antibody recognizing IGF-IR $\beta$ chain. IGF-IR expression is increased as shown by the example blots of three patients (A), and by the quantification of the eight couples of samples (B). Quantitative data were plotted as described and reported as percentage, where the $100 \%$ value was attributed to the non-Npl sample. Statistical analyses were performed with Fisher's test $(P=0.032)$. Npl samples are richer in IGF-IR that are also ubiquitinated more than Non Npl (C) The IGFIR tyrosine phosphorylation of both types of tissues increased after 30 min incubation with IGF-I (D) that increased also the receptor ubiquitination in non-Npl (E) and $\mathrm{Npl}$ tissue (not shown). Equal amount of proteins $(500 \mu \mathrm{g})$, from bits of $\mathrm{Npl}$ and non-Npl homogenates from lung tissues of the same patient, were immunoprecipitated with anti-IGF-IR $\beta$ chain polyclonal antibody as reported in "Materials and Methods." Each immunoprecipitated sample was equally divided for being analyzed with anti-ubiquitin-conjugated proteins antibody and anti-IGF-IR $\beta$ chain antibody. The results are representative of five independent experiments. Fresh small bits of non-Npl and $\mathrm{Npl}$ lung specimens were incubated with rhuIGF-I $(50 \mathrm{ng} / \mathrm{ml})$ for $30 \mathrm{~min}$. Assay was harvested as described in "Materials and Methods." IGF-IR $\beta$ chain was immunopurified from protein extracts $(300 \mu \mathrm{g})$. The eluted samples were equally divided and analyzed (C) for ubiquitination, and (D) for phosphorylation. The results are representative of two different experiments. 
A
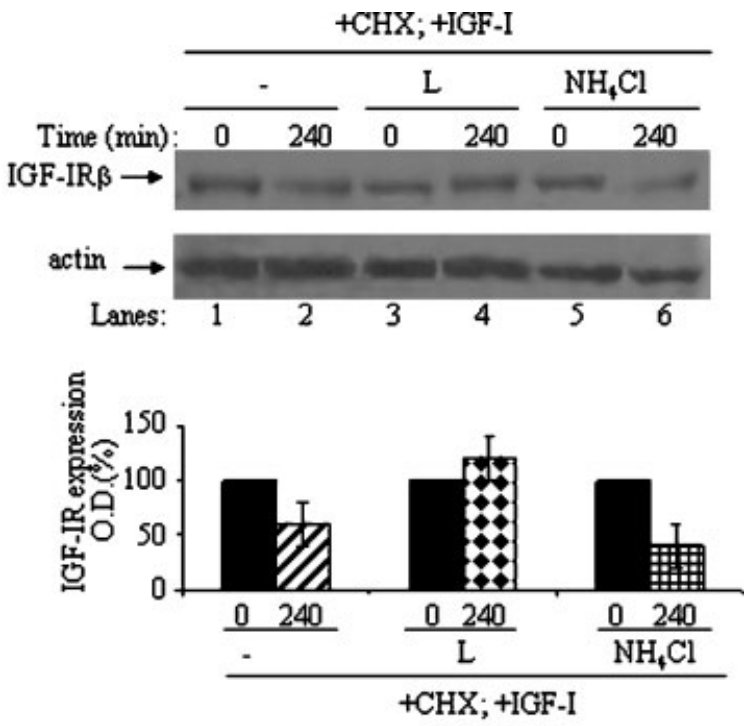

B
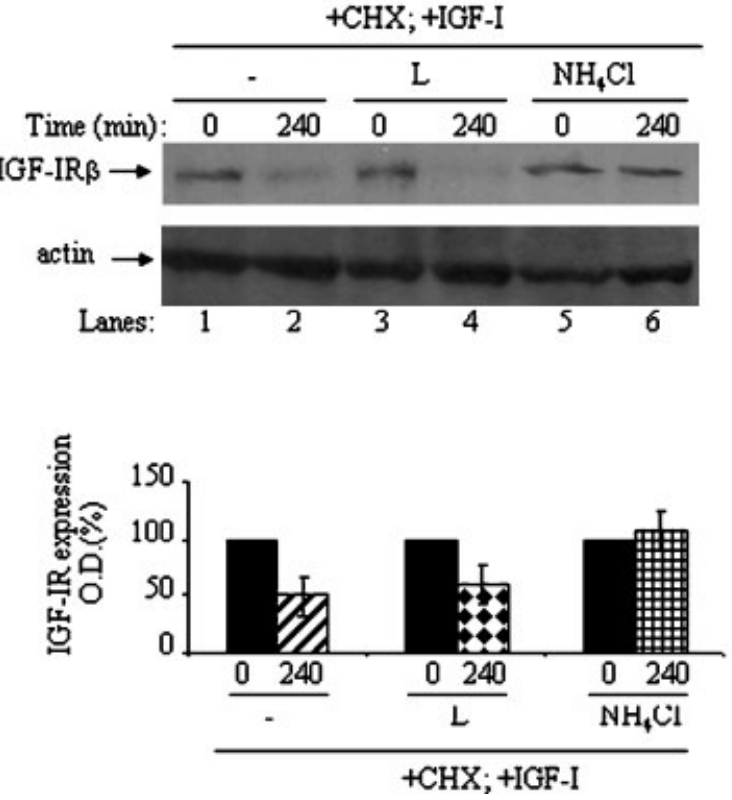

Fig. 5. Different fate of IGF-IR $\beta$ chain degradation in human $\mathrm{Npl}$ and non-Npl lung specimens. A: IGF-IR $\beta$ chain degradation was studied in lung tumor specimen, and (B) in non-Npl lung specimen. The results are representative of two independent experiments. As internal control of gel loading, membranes were decorated with anti- $\beta$ actin antibody. The experimental procedures are similar to those of Figures 2 and 3. IGF-I exposure in presence of CHX causes a marked drop of IGF-IR $\beta$ chain that is prevented by lactacystin (L) and unaffected by $\mathrm{NH}_{4} \mathrm{Cl}$ in Npl tissue (A). Conversely, the degradation is unaffected by lactacystin and blocked by $\mathrm{NH}_{4} \mathrm{Cl}$ in non-Npl tissue (B).

and in fresh specimens of lung tumor. Conversely, IGFIR $\beta$ chain is degraded via the lysosomal pathway in non$\mathrm{Npl}$ lung tissue specimens. In addition, we observed that the process of receptor downregulation is energy dependent, a fundamental hallmark for protein degradation by means of the ubiquitin-proteasome system that requires ATP for the conjugation of ubiquitin moieties and the assembly of the proteasome (Aviel et al., 2000).

Mono-ubiquitination of endocytic proteins and RTKs is a critical sorting signal in endocytosis (Di Fiore et al., 2003; Haglund et al., 2003). The binding of the ligand to
A

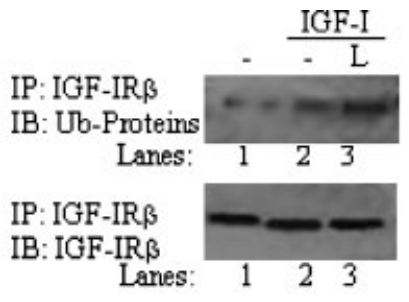

B

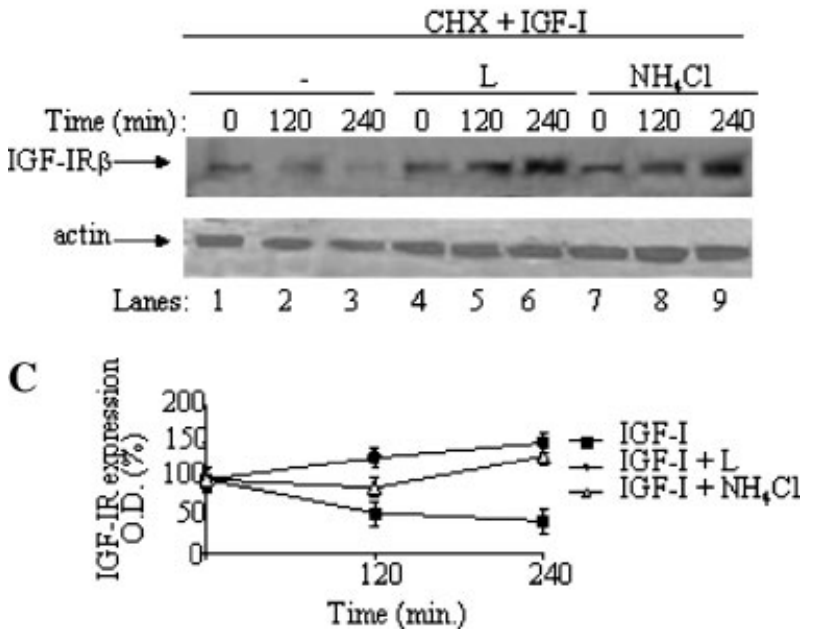

Fig. 6. IGF-IR $\beta$ chain ubiquitination and degradation in IMR90 cells. A: Ubiquitination of IGF-IR $\beta$ chain was investigated as described in "Materials and Methods." Briefly, cells were incubated with rhuIGF-I $(150 \mathrm{ng} / \mathrm{ml})$ for $30 \mathrm{~min}$, and to inhibit proteasome degradation lactacystin $(\mathrm{L}, 10 \mu \mathrm{M})$ was added to the medium (lane 3 ), IGF-I exposure increases IGF-IR ubiquitination and this is further increased by lactacystin. B: Ligand-induced IGF-IR $\beta$ chain degradation was investigated as described above. Both lactacystin $(\mathrm{L}, 10 \mu \mathrm{M})$ and $\mathrm{NH}_{4} \mathrm{Cl}(10 \mathrm{mM})$ prevented the IGF-IR $\beta$ chain drop. $\mathbf{C}$ : Band intensities were quantified by analysis of the imaging data, normalized to $\beta$-actin levels and plotted as a relative percentage of the signal at time 0 . Data are expressed as the mean of three independent experiments $\pm \mathrm{SD}$.

its specific receptor is required for the ubiquitination of several cell receptors such as T-cell receptor $\xi$ chain (Hou et al., 1994), EGFR (Stang et al., 2000), plateletderived growth factor receptor (Mori et al., 1993), and GH receptor (Strous et al., 1997). A quick autophosphorylation of IGF-IR $\beta$ chain is observed after incubation with the specific ligand (Ebina et al., 1985; Ullrich et al., 1985). In our experimental conditions, IGF-IR $\beta$ chain autophosphorylation is followed by ubiquitination. Such type of sequential process is an essential step for the activation of ubiquitin-proteasome pathway in the case of several other substrates including $\mathrm{I} \kappa \mathrm{B} \alpha, \mathrm{G} 1$ cyclins, mammalian CDK inhibitor $\mathrm{p} 27^{\mathrm{KIP} 1}$, and $\beta$ catenin (Kornitzer and Ciechanover, 2000). Here we report that IGF-I-dependent phosphorylation of IGF-IR $\beta$ chain and its consequent ubiquitination occur both in cell lines and in ex vivo bits of non-Npl and Npl lung tissues. This is consistent with previous observations in melanoma cells, where IGF-IR downregulation was related to p53 suppression that controls its $\mathrm{Mdm} 2$ dependent ubiquitination and degradation (Girnita et al., 2003). Moreover, our observations that ubiquitination of IGF-IR takes place in both $\mathrm{Npl}$ and non-Npl specimens suggest that this post-translational modification represents a necessary step for the degradation of this receptor independently by the final mechanism employed by the cells. The receptor downregulation in 
$\mathrm{Npl}$ lung cell lines and in fresh $\mathrm{Npl}$ tissue specimens was sensitive to blockade of proteasomal activity, which determined a stabilization of IGF-IR $\beta$ chain. While, a clear degradation of the protein was observed when the lysosomal activity was inhibited. Moreover, in tumor cells, the inhibition of the proteasome was accompanied by accumulation of ubiquitinated IGF-IR $\beta$ chain. These evidences clearly indicate that, in lung cancer, the $\beta$ chain of IGF-IR is solely degraded by means of the proteasome system with no switch to the other system when the proteasome is inhibited. Conversely, the degradation assay performed in non-Npl lung tissue specimens showed that ligand-induced receptor $\beta$ chain degradation occurs by means of active lysosomal functions. Our present observation that lysosomal inhibitors do not affect receptor degradation in lung tumor cells does not exclude the possibility that lysosomal proteolysis may contribute to the degradation of partially digested IGF-IR, as it was previously suggested for PDGF- $\beta$ receptor (Mori et al., 1993). We have, in fact, monitored the fate of full-length IGF-IR $\beta$ chain, while the partially cleaved $\beta$ chain molecules, due to their unpredictable changes in molecular size and immunological reactivity, could not be detected accurately. As shown in Figure 2F, EGFR is degraded by the lysosomal system in A549 cells, thus the switch to the proteosomal degradation pathway is not a general phenomenon in lung cancer cells, and may represent a peculiarity of IGF-IR.

Differently from adult cells, human normal lung cells of fetal origin (IMR90) employ both proteasome and lysosomal pathways for IGF-IR downregulation. Such co-existence of both degradation pathways for IGF-IR was also observed in P6 mouse embryo fibroblasts transfected with adaptor protein Grb10 and overexpressing IGF-IR (Vecchione et al., 2003). In this study we observed that undifferentiated IMR90 cells employ a degradation mechanism in which proteasome and lysosome cooperate for the degradation of IGF-IR since the inhibition of one is sufficient to cause receptor accumulation. Although lactacystin appears more effective suggesting a major role for the proteasome. The lack of such dual interdependence in adult cells suggest that during cell development and differentiation, this dual route of degradation is driven towards a single mechanism with the prevalence of the lysosomal pathway in normal healthy cells. Conversely, the progenitor cancer cells might have reactivated the originally suppressed ubiquitin-proteasome pathway with an hypothetical consequent inactivation of the lysosomal route. Recently, it has been proposed that the protein machinery that utilizes ubiquitination for ensuring proper endocytosis and degradation of RTKs may regulate the choice of one way rather than the other (Bache et al., 2004). The link between these activation and inactivation processes is still unclear, and might be related to events involved in tumor initiation and development. This is the case of human hematopoietic malignancies where proteins, such as Eps15, endophilin-2, rabaptin-5, are involved in a faulty organization of clathrin-coated vesicles and endosomal fusion due to their abnormal structure caused by the rearrangement of their genes with oncogenic loci. This subversion might be the basis of the initiating steps in $\mathrm{Npl}$ development (reviewed in Bache et al., 2004; Polo et al., 2004).

The circulating levels of IGF-I influence many IGFIR-positive cancers, thus tumor behavior might be regulated by IGF-I secreted in autocrine, paracrine, and endocrine manners (Pollak et al., 2004). A recent meta-analysis (Renehan et al., 2004) of all published studies on the association between IGF-I and tumor risk described an increment in cancer risk in prostate, colorectal, and pre-menopausal breast malignancies. The circulating IGF-I concentrations were not related to any lung cancer risk. Thus our results suggest that, rather than IGF-I, IGF-IR expression and degradation may play a role in lung cancer. IGF-IR is often overexpressed in malignant tumors of tyroid, colon, prostate, and in synovial carcinoma (Werner et al., 1989; Werner, 1998; Belfiore et al., 1999; All-Ericsson et al., 2002; Samani et al., 2004). The mechanisms behind such cellular upregulation are not clearly understood. Other authors have suggested that the degradation processes may represent a crucial step in such development (Larsson et al., 2005), and our studies may support this hypothesis. Recently, the exposure of human cell lines, MCF-7 and A549, to specific antibodies against IGF-IR, was able to inhibit receptor signaling, cell cycle progression, and promote degradation of the receptor. Importantly, this approach increased the tumor sensitivity to other therapeutic compounds such as vinorelbine (Goetsch et al., 2005). Moreover, it is becoming apparent that endocytic routes taken by the receptors, such as EGF receptor (Haglung and Dikic, 2005; Sigismund et al., 2005), neutrophin receptors (Zhang et al., 2000), and transforming growth factor (TGF)- $\beta$ receptor (Di Guglielmo et al., 2003), may influence their signaling quality, strength, and duration, and concerning to that, ubiquitination play an important role in directing sub-cellular localization and intracellular traffic of receptors (Haglund et al., 2003).

In conclusion, we show that IGF-IR $\beta$ chain is overexpressed in NSCLC tissue homogenates, this might be related to changes in endocytosis and degradation events that are involved in IGF-IR downregulation. IGF-IR is degraded via ubiquitin-proteasome pathway in $\mathrm{Npl}$ cell lines and fresh tissue specimens from NSCLC, while the lysosomal route is employed in nonNpl lung tissue. Our evidences of the existence of a divergent degradation route of IGF-IR in non-Npl and $\mathrm{Npl}$ lung cells might also suggest that the receptor signals might be different in the two cell types, and that it could be an appropriate target for novel pharmacological approaches to IGF-IR-positive cancers.

\section{ACKNOWLEDGMENTS}

This work was supported by FIRB 2002 Programme of the Ministero Italiano dell'Università e della Ricerca (MIUR), Grant No. RBAUOIL79J.

\section{LITERATURE CITED}

All-Ericsson C, Girnita L, Seregard S, Bartolazzi A, Jager MJ, Larsson P. 2002 Insulin-like growth factor-1 receptor in uveal melanoma: A predictor for metastatic disease and a potential therapeutic target. Invest Ophthalmol Vis Sci 43:1-8

Aviel S, Winberg G, Massucci M, Ciechanover A. 2000. Degradation of the Aviel S, Winberg G, Massucci M, Ciechanover A. 2000. Degradation of the
epstein-barr virus latent membrane protein 1 (LMP1) by the ubiquitinproteasome pathway. Targeting via ubiquitination of the $\mathrm{N}$-terminal residue. J Biol Chem 275:23491-23499.

Bache KG, Slagsvold T, Stenmark H. 2004. Defective downregulation of receptor tyrosine kinase in cancer. EMBO J 23:2707-2712.

Baserga R. 1995. The insulin-like growth factor I receptor: A key to tumor growth? Cancer Res 55:249-252.

Baserga R, Resnicoff M, Dews M. 1997. The IGF-I receptor and cancer. Endocrine 7:99-102

Belfiore A, Pandini G, Vella V, Squatrito S, Vigneri R. 1999. Insulin/IGF-I receptor kinase. Biochimie 81:403-407.

Bonifacino JS, Weissman AM. 1998. Ubiquitin and the control of protein fate in the secretory and endocytic pathways. Annu Rev Cell Dev Biol 14:19-57.

Carpentier JL. 1994. Insulin receptor internalization: Molecular mechanisms and physiopathological implications. Diabetologia 37:S117-S124.

Carro E, Trejo JL, Gomez-Isla T, Le Roith D, Torres-Aleman A. 2002. Serum insulin-like growth factor I regulates brain amyloid-beta levels. Nat Med 8:1390-1397. 
Ciechanover A. 1998. The ubiquitin-proteasome pathway: On protein death and cell life. EMBO J 17:7151-7160.

Ciechanover A, Orian A, Schwartz AL. 2000. The ubiquitin-mediated proteolytic pathway: Mode of action and clinical implications. J Cell Biochem 34:40-51.

Di Fiore PP, Polo S, Hofmann K. 2003. When ubiquitin meets ubiquitin receptors: A signalling connection. Nat Rev Mol Cell Biol 4:491-497.

Di Guglielmo GM, Le Roy C, Goodfellow AF, Wrana JL. 2003. Distinct endocytic pathways regulate TGF-beta receptor signalling and turnover. Nat Cell Biol $5: 382-384$

Ebina Y, Ellis L, Jarnagin K, Edery M, Graf L, Clauser E, Ou JH, Masiarz F, Kan YW, Goldfine ID. 1985. The human insulin receptor cDNA: The structural basis for hormone-activated transmembrane signalling. Cell 40:747-758.

Furlanetto RW. 1988. Receptor-mediated endocytosis and lysosomal processing of insulin-like growth factor I by mitogenically responsive cells. Endocrinology 122:44-53

Girnita L, Girnita A, Larsson O. 2003. Mdm2-dependent ubiquitination and degradation of the insulin-like growth factor 1 receptor. Mdm2-dependent ubiquitination and degradation of the insulin-like growth factor 1 receptor. Proc Natl Acad Sci USA 100:8247-8252.

Goetsch L, Gonzalez A, Leger O, Beck A, Pauwels PJ, Haeuw JF, Corvaia N. 2005. A recombinant humanized anti-insulin-like growth factor receptor type I antibody (h7C10) enhances the antitumor activity of vinorelbine and antiepidermal growth factor receptor therapy against human cancer xenografts. Int J Cancer 113:316-328.

Govers R, van Kerkhof P, Schwartz AL, Strous GJ. 1997. Linkage of the ubiquitin-conjugating system and the endocytic pathway in ligand-induced internalization of the growth hormone receptor. EMBO J 16:4851-4858.

Haglund K, Sigismund S, Polo S, Szymkiewicz I, Di Fiore PP, Dikic I. 2003 Multiple monoubiquitination of RTKs is sufficient for their endocytosis and degradation. Nat Cell Biol 5:461-466.

Haglung K, Dikic I. 2005. Ubiquitylation and cell signaling. EMBO J. 24:33533359

Hicke L. 1999. Gettin' down with ubiquitin: Turning off cell-surface receptors, transporters and channels. Trends Cell Biol 9:107-112.

Hicke L, Riezman H. 1996. Ubiquitination of a yeast plasma membrane receptor signals its ligand-stimulated endocytosis. Cell 84:277-287.

Hou D, Cenciarelli C, Jensen JP, Nguygen HB, Weissman AM. 1994. Activationdependent ubiquitination of a $\mathrm{T}$ cell antigen receptor subunit on multiple intracellular lysines. J Biol Chem 269:14244-14247.

Jones JI, Clemmons DR. 1995. Insulin-like growth factors and their binding proteins: Biological actions. Endocr Rev 16:3-34.

Koenig JA, Edwardson JM. 1997. Endocytosis and recycling of G protein-coupled receptors. Trends Pharmacol Sci 18:276-287.

Kornitzer D, Ciechanover A. 2000. Modes of regulation of ubiquitin-mediated protein degradation. J Cell Physiol 182:1-11.

Larsson O, Girnita A, Girnita L. 2005. Role of insulin-like growth factor I receptor signalling in cancer. Br J Cancer 92:2097-2101.

Lowry OH, Rosenburg NJ, Farr AL, Randall RJ. 1951. Protein measurement with the Folin phenol reagent. J Biol Chem 193:265-275.

Mori S, Heldin CH, Claesson-Welsh L. 1993. Ligand-induced polyubiquitination of the platelet-derived growth factor beta-receptor. J Biol Chem 26:64296434

Navab R, Chevet E, Authier F, Di Guglielmo GM, Bergeron JM, Brodt P. 2001. Inhibition of endosomal insulin-like growth factor-I processing by cysteine proteinase inhibitors blocks receptor-mediated functions. J Biol Chem 276: $13644-13649$.

Pearse BM, Robinson MS. 1990. Clathrin, adaptors, and sorting. Annu Rev Cell Biol 6:151-171.

Pollak MN, Schernhammer ES, Hankinson SE. 2004. Insulin-like growth factors and neoplasia. Nat Rev Cancer 4:505-518.

Polo S, Pece S, Di Fiore PP. 2004. Endocytosis and cancer. Curr Opin Cell Biol 16:156-161.
Pronk GJ, McGlade J, Pelicci G, Pawson T, Bos JL. 1993. Insulin-induced phosphorylation of the 46- and 52-kDa Shc proteins. J Biol Chem 268:5748-5753. Renehan AG, Zwahlen M, Minder C, O'Dwyer ST, Shalet SM, Egger M. 2004. Insulin-like growth factor (IGF)-I, IGF binding protein-3, and cancer risk: Systematic review and meta-regression analysis. Lancet 363:1346-1353.

Reneke JE, Blumer KJ, Courchesne WE, Thorner J. 1988. The carboxy-terminal segment of the yeast alpha-factor receptor is a regulatory domain. Cell 55:221234

Robinson MS. 1994. The role of clathrin, adaptors and dynamin in endocytosis. Curr Opin Cell Biol 6:538-544.

Roth AF, Davies NG. 1996. Ubiquitination of the yeast a-factor receptor. J Cell Biol 134:661-674.

Samani AA, Chevet E, Fallavollita L, Galipeau J, Brodt P. 2004. Loss of tumorigenicity and metastatic potential in carcinoma cells expressing the extracellular domain of the type 1 insulin-like growth factor receptor. Cancer Res 64:3380-3385.

Sigismund S, Woelk T, Puri C, Maspero E, Tacchetti C, Transidico P, Di Fiore PP Polo S. 2005. Clathrin-independent endocytosis of ubiquitinated cargos. Proc Natl Acad Sci USA 102:2760-2765.

Stang E, Johannessen LE, Knardal SL, Madshus IH. 2000. Polyubiquitination of the epidermal growth factor receptor occurs at the plasma membrane upon ligand-induced activation. J Biol Chem 275:13940-13947.

Staub O, Gautschi I, Ishikawa T, Breitschopf K, Ciechanover A, Schild L, Rotin D. 1997. Regulation of stability and function of the epithelial $\mathrm{Na}^{+}$channel (ENaC) by ubiquitination. EMBO J 16:6325-6333.

Stewart CEH, Rotwein P. 1996. Growth, differentiation, and survival: Multiple physiological functions for insulin-like growth factors. Physiol Rev 76:10051026 .

Strous GJ, van Kerkhof P, Govers R, Ciechanover A, Schwartz AL. 1996. Th ubiquitin conjugation system is required for ligand-induced endocytosis and degradation of the growth hormone receptor. EMBO J 15:3806-3812.

Strous GJ, van Kerkhof P, Govers R, Rotwein P, Schwartz AL. 1997. Growth hormone-induced signal transduction depends on an intact ubiquitin system. J Biol Chem 272:40-43.

Sun XJ, Wang LM, Zhang Y, Yenush L, Myers MG, Jr., Glasheen E, Lane WS, Pierce JH, White MF. 1995. Role of IRS-2 in insulin and cytokine signalling. Nature 377:173-177.

Ullrich A, Bell JR, Chen EY, Herrera R, Petruzzelli LM, Dull TJ, Gray A Coussens L, Liao YC, Tsubokawa M. 1985. Human insulin receptor and its relationship to the tyrosine kinase family of oncogenes. Nature 313:756 761.

Vecchione A, Marchese A, Henry P, Rotin D, Morrione A. 2003. The Grb10/Nedd complex regulates ligand-induced ubiquitination and stability of the insulinlike growth factor I receptor. Mol Cell Biol 23:3363-3372.

Wang LM, Myers MG, Jr., Sun XJ, Aaronson SA, White M, Pierce JH. 1993. IRS1: Essential for insulin- and IL-4-stimulated mitogenesis in hematopoietic cells Science 261:1591-1594.

Werner H. 1998. Dysregulation of the type 1 IGF receptor as a paradigm in tumor progression. Mol Cell Endocrinol 141:1-5.

Werner H, Le Roith D. 1997. The insulin-like growth factor-I receptor signaling pathways are important for tumorigenesis and inhibition of apoptosis. Crit Rev Oncog 8:71-92

Werner H, Woloschak M, Adamo M, Shen-Orr Z, Roberts CT, Jr., Le Roith D. 1989. Developmental regulation of the rat insulin-like growth factor I receptor gene. Proc Natl Acad Sci USA 86:7451-7455.

White MF, Kahn CR. 1994. The insulin signalling system. J Biol Chem 269:1-4.

Xie Y, Skytting B, Nilsson G, Brodin B, Larsson O 1999. Expression of insulinlike growth factor-I receptor in synovial sarcoma: Association with an aggressive phenotype. Cancer Res 59:3588-3591.

Zhang Y-Z, Moheban DB, Conway BR, Bhattacharya A, Segal RA. 2000. Cel surface Trk receptors mediate NGF-induced survival while internalized receptors regulate NGF-induced differentiation. J Neurosci 20:5671-5678. 